\section{Conferencia AMEE 2009}

Madalena Patricio a, Jordi Palés ${ }^{\text {b }}$

\section{The 2009 AMEE Conference}

La educación médica en general y en Europa en particular se encuentra en una de las etapas más desafiantes de su existencia, debido a la complejidad de los cambios que se avecinan y que demandan un esfuerzo continuado para su adaptación a los mismos y llevar a cabo las consiguientes reformas.

En la actualidad está ampliamente aceptado que la educación médica debe hacer frente a los determinantes de los cambios actuales teniendo en cuenta principalmente:

- La globalización.

- La explosión de los conocimientos médicos.

- Las nuevas expectativas y demandas y los nuevos derechos de los pacientes.

- Las nuevas tecnologías para la enseñanza y el aprendizaje.

- El proceso de Bolonia.

El 'cambio por el cambio' ya no es aceptable. La evaluación del proceso de reforma es inevitable, lo que implica el análisis de la situación con el fin de responder a preguntas como: 'por qué necesitamos cambiar', 'qué deberíamos cambiar' 'cuando deberíamos cambiar' y 'quiénes deben liderar el cambio'.

La Conferencia anual de la AMEE puede desempeñar un papel importante en el sentido de implementar el cambio. Poniendo en contacto a educadores, profesores, estudiantes, investigadores y otros agentes, es decir, toda la comunidad educativa médica, la conferencia ofrece a los participantes la oportunidad de actualizar la información sobre los desarrollos en educación médica, discutir las buenas prácticas e incrementar el trabajo en red.
Medical education in general and specially in Europe is going through one of the most challenging phases of its existence due to the complexity of undergoing changes demanding a continuous effort towards adaptation and consequent reforms.

It is now widely accepted that medical education must cope with the determinants of present changes namely taking into account:

- Globalisation.

- Explosion of medical knowledge.

- Patient's new expectations, new demands, new rights.

- New teaching and learning technologies.

- Bologna process.

As 'change for change sake' is no longer acceptable, the evaluation of the process under reform is therefore unavoidable, implying the analysis of the situation in order to answer questions like 'why do we need to change', 'what should be changed' ' when should we change' and 'who should be the leader for change'.

The AMEE Annual Conference may play a fundamental role in terms of implementing change. Bringing together educationalists, teachers, students, researchers and other stakeholders, i.e. the whole medical education community, the conference offers participants the opportunity to update information about developments in medical education, discuss good practices and increase networking.

Moreover, the AMEE Annual Conference by its nature can be considered the international opportunity for collaborative learning with participants a Presidenta de AMEE.

${ }^{b}$ Presidente de SEDEM.

E-mails

a patricio@fm.ul.pt

bjpales@ub.edu 
La Conferencia de la AMEE, por su naturale$\mathrm{za}$, debe considerarse como una oportunidad internacional para el aprendizaje cooperativo con los participantes implicados en compartir buenas prácticas y poder aplicarlas en su medio con el fin de conseguir un mayor progreso de la educación. Teniendo en cuenta estos aspectos, SEDEM y FEM les animan a participar en la Conferencia AMEE 2009 que tendrá lugar en Málaga del 29 de agosto al 2 de septiembre próximos.

Un año antes del plazo establecido en la Declaración de Bolonia por los países firmantes para finalizar el proceso de la deseada armonización, la Conferencia de la AMEE, reuniendo a los profesionales de las ciencias de la salud, constituye una excelente oportunidad para conocer las últimas tendencias en educación médica e intercambiar experiencias de la práctica diaria.

Prometemos una conferencia estimulante. La Conferencia de la AMEE, probablemente la mayor reunión mundial dedicada a la educación médica, cubre:

- El continuo educativo, desde la formación pregraduada/básica hasta el desarrollo profesional continuo y la formación médica continuada, pasando por la formación posgraduada y especializada.

- Un amplio abanico de profesionales implicados en la atención sanitaria y, por ello, el tema de la educación multiprofesional es un aspecto importante en la Conferencia de la AMEE.

- Un amplio abanico de perfiles en los participantes, desde los educadores noveles y los más experimentados a los investigadores, especialistas, decanos, administradores y, desde luego, estudiantes, que están desempeñando un papel importante en las conferencias de la AMEE.

A fecha de hoy se han recibido 1.780 resúmenes en forma de comunicaciones libres y paneles y 140 para los talleres. Basándonos en las cifras de la Conferencia de Praga de 2008, a la que acudieron 2.300 participantes de más de 80 países, se prevé una fructífera discusión sobre el futuro de la educación médica basada en la riqueza de la experiencia de los participantes.

La Conferencia AMEE 2009 anima a acercarse al mayor reto en de la educación médica, principalmente, pasar de una perspectiva centrada en el estudiante a una perspectiva transnacional centrada en el estudiante, un cambio que demanda actitudes, valores y prioridades además de competencias téc- engaged in sharing the good lessons to be taken home towards a wider progress in medical education. Having this in mind SEDEM and FEM would like to stimulate to attend the 2009 AMEE Conference which will take place in Malaga from $29 \mathrm{Au}$ gust to 2 September.

A year before the deadline established by the Bologna Process for signatory countries to achieve the desired harmonisation the AMEE Conference in Malaga, bringing together medical and other health care professionals, constitutes an excellent opportunity for participants' updated on the latest trends in medical education and exchange experiences from their daily practice

We promise you a challenging conference. Probably the biggest meeting in the world dedicated to medical education, the AMEE Conference covers

- The continuum of education, from undergraduate/basic training, through postgraduate/specialist training to continuing professional development/ continuing medical education.

- The continuum of professionals dealing with healthcare as multiprofessional education is a high theme at the AMEE Conference.

- The continuum of participants' profiles from new and experienced teachers to researchers, specialists, deans, administrators, policy-makers and of course students, who are playing an increasingly important role in AMEE Conference.

So far we have received 1780 abstracts for short communications and posters and 140 for workshops. Based on figures from last year Conference in Prague, where we had 2300 participants from more than 80 countries, we anticipate a fruitful discussion on the future for medical education based on richness of participants' experience.

AMEE 2009 will help us to approach the greatest challenge in medical education namely the way to move from a student centred to a transnational student-centred perspective, a change involving attitudes, values, and priorities in addition to technical and scientific competencies. At the AMEE in Malaga successful experiences will be shared among the medical education community so that participants can bring home ideas for implementing progress without necessarily having to 'reinvent the wheel'.

The main topics of the Conference will be:

- Evidence based view on global health.

- Rethinking medical education. 
nicas y competencias científicas. En la Conferencia de la AMEE podrán intercambiarse entre los miembros de la comunidad educativa médica experiencias exitosas de tal forma que los participantes pueden llevarse consigo ideas para implementarlas sin necesidad de 'reinventar la rueda'.

Los temas relevantes de la Conferencia serán:

- Visión de la salud global basada en la evidencia.

- Repensando la educación médica.

- Nuevos horizontes en simulación.

- Aspectos éticos en la investigación en educación médica.

- El clínico/el investigador se encuentra con el educador.

- Mejores practicas globales en formación médica continuada.

- Pánico moral, imperativo político y aquello que la profesión sabe acerca del desarrollo de sus nuevas generaciones.

- Aprendizaje clínico.

- Evolución de la evaluación de las habilidades clínicas.

- Educación posgraduada basada en la competencia.

- Enseñando ciencias básicas a los estudiantes y residentes.

- El proceso de Bolonia.

- Nuevas perspectivas del desarrollo de los docentes.

- Aprendizaje, evaluación, tecnología: en este orden.

Es un placer para la Sociedad Española de Educación Médica poder compartir en esta edición su XIX Congreso con el mayor congreso internacional de educación médica, en el marco de la excelente colaboración que siempre ha existido entre la AMEE y la SEDEM. Este congreso conjunto destinará espacios o actividades en castellano dirigidas específicamente a los educadores médicos del ámbito cultural de habla hispana. Se prevé discutir temas de actualidad, como los cambios curriculares en el contexto del proceso de Bolonia o los aspectos relacionados con la responsabilidad ética y social de los profesores y de las Facultades de Medicina. Así mismo, se celebrarán talleres en castellano sobre temas como la evaluación de las competencias o la formación médica posgraduada.

Desde este editorial queremos animar a todos los educadores médicos a no dejar pasar esta oportunidad única de participar en el principal congreso mundial de educación médica, aportando sus experiencias e intercambiándolas con colegas procedentes de más de 80 países.
- New horizons in simulation.

- Ethical issues in medical education research.

- Clinician/researcher meets educator.

- Global best practices in continuing medical education.

- Moral panic, political imperative and what the profession knows about the developing its new generations.

- Clinical learning.

- Evolution of clinical skills assessment.

- Competency based postgraduate education.

- Teaching basic sciences to students and residents.

- The Bologna process.

- New perspective on faculty development.

- International collaboration.

- Learning, assessment, technology: in that order.

It is a pleasure for the Spanish Society of Medical Education (SEDEM) to act this year as local host and to share our Nineteenth Meeting with the greatest International Meeting in Medical Education in the context of the constant excellent collaboration between AMEE and SEDEM.

This Joint meeting will devote different spaces and activities in Spanish, addressed especially to medical educators from cultural field of Spain and LatinAmerican. In these activities, important topics as the current curricular changes according to Bologna process, the ethic and social accountability of teachers and medical schools will be discussed. Otherwise some different workshops in Spanish will be developed, on different topics as the assessment of clinical competences or the postgraduate medical education.

From this editorial we want to stimulate medical educators to joint us and dot to miss this opportunity to participate in the most important world medical education conference, bringing their experiences and sharing them with colleagues from more of 80 countries. 